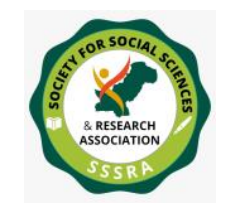

Pak. Journal of Int'L Affairs, Vol 4, Issue 2 (2021) The Influence of International Public Opinion ...

\title{
The Influence of International Public Opinion on Pak-Afghan Border Management
}

\author{
JIANG Sheng \\ PhD from Shanghai International Studies University \\ Shanghai-China. \\ shengjiang@shisu.edu.cn \\ Dr. Allauddin kakar \\ Assistant Professor/DS Research \\ Command and Staff Collage \\ Quetta, Balochistan \\ allauddin_kakar@yahoo.com \\ Ghulam Dastagir \\ Lecturer \\ Department of International Relations \\ University of Balochistan, Quetta. \\ dastagir76@gmail.com
}

\begin{abstract}
This research paper examines the influence of International Public Opinion on Pakistan-Afghanistan border management. Though Durand Line is a recognized border between Pakistan and Afghanistan, but its management has been a source of contention between the two neighboring countries. The long porous border between Pakistan and Afghanistan remained threat to Pakistan's security. In 2016, Pakistan started fencing work on its border with Afghanistan which was indeed a significant step towards border management. During the last two decades, relationships between Pakistan and Afghanistan reached their lowest level due to a number of clashes along Pak-Afghan border. The traditional media along with new media technologies has increased the scope of International Public Opinion or World Opinion as well as its influence on international events. The paper explores the leverage and impacts of International Public Opinion on border management between Pakistan and Afghanistan and highlight the significance of positive International Opinion on this border management. This paper highlights reports of global
\end{abstract}

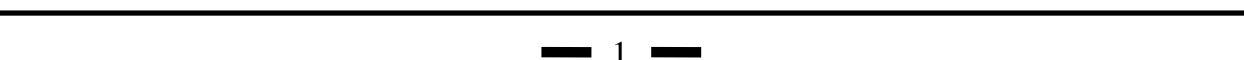




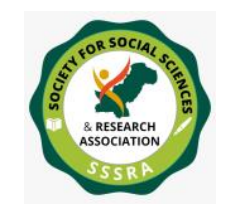

Pak. Journal of Int'L Affairs, Vol 4, Issue 2 (2021) The Influence of International Public Opinion ...

organizations, international media, role of social media, and state policies and their efforts in resolving Pak-Afghan border management issues.

Keywords: World opinion, Afghanistan, Pakistan, Border management, Durand Line.

\section{Introduction}

Traditional media coupled with advanced information technologies has enhanced the flow of international news available to the general public faster than before. Hence, the concept of international public opinion or world opinion is growing and its scope is widening (Omar, 2014). The advanced media tools and availability of diverse information has made it more influential. Pakistan and Afghanistan are neighboring countries and share close religious, cultural, geo-political and economic linkages. The two countries have about $2500 \mathrm{~km}$ common border formally called as Durand Line. Relationships between Pakistan and Afghanistan have been tense since the former inception in year 1947. Afghanistan has seen foreign invasions during the last five decades which have deeply effected its peace, stability and development. The internal security dynamics of Afghanistan has remained threats to Pakistan internal security environment. Besides, the long porous Pak-Afghan border remained source of contention between the two immediate neighbors. Illicit trade activities, drug trafficking, smuggling, free movements of terrorists across the border have been blocking factors in bilateral relationships between Pakistan and Afghanistan. After Soviet invasion of Afghanistan, a large number of Afghani people took refuge in Pakistan. Border management has been the most-talked about issue for Pakistani policy makers during the last seven decades. A positive international public opinion is imperative for peaceful and stable environment in both countries, and even it is crucial for the stability and development of the entire region. Particularity of international public opinion plays significant role in determining Pak-Afghan border management, which will undeniably have profound positive impact.

Border management system is internationally recognized, successful border management and trustworthy bilateral ties depend on joint surveillance systems and mutual agreements on border related issues. In case of Pak-Afghan border, Pakistan typically makes unilateral decisions because of lack of interest on the Afghan side. "The international public opinion is thought to be the emanation of an international debate in gestation. It is seized through its demonstrations: for example, in 2003, converging mobilizations against the war in Iraq, the United States, Egypt, Indonesia, etc." (Osée, Bijoux, Didier, \& François, 2019). For smooth economic growth and improve security of a state, it is imperative to ensure security of border areas. Recent examples of border management are that of US-Mexico border and border between India and Bangladesh. 


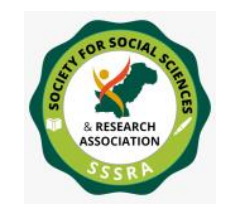

Pak. Journal of Int'L Affairs, Vol 4, Issue 2 (2021) The Influence of International Public Opinion ...

The US is fencing its border under 'Secure Fence Act' to ensure security of border land. In the same way, India has also fenced its border with Bangladesh for security reasons.

In case of Pakistan, it shares long porous border with Afghanistan which always generated security threats to Pakistan and damages to its national economy due to illicit trade activities and drug trafficking and smuggling etc. (Rauf, \& Ahmad, 2019). Border management and positive international opinions would help in preventing illicit trade activities such as drug trafficking and smuggling etc. At present, Pakistan is working on border fencing and almost $80 \%$ of work has been completed. The remaining work of fencing project is expected to complete by the end of 2021 (Shahid, 2021, January 27). Border fencing is a milestone initiative by Pakistan which will considerably decline in terrorist movements and illegal trade.

\section{International Public Opinion}

Traditional media coupled with new information technologies is enhancing the flow of international news available to the general public faster than before. Therefore, the concept of international public opinion or world opinion growing. The widespread availability of diverse information is enhancing its scope and significance and making it more influential in the field of international diplomacy.

"Public opinion is critical because it is a key component of the socio-political context within which policy makers operate. Public opinion can fundamentally compel or constrain political, economic and social action to address particular risks" (Leiserowitz, 2007).

"The international public is a form of social grouping that consists of individuals or groups of different countries that acquire images, general or particular, and perform common evaluations on international events from the information provided by their insertion into transnational communication flows" (Calduch Cervera, 2017).

\section{Impacts Of World Opinion on Pak-Afghan Border Management}

"The international public is a form of social grouping that consists of individuals or groups of different countries that acquire images, general or particular, and perform common evaluations on international events from the information provided by their insertion into transnational communication flows." Border between Pakistan and Afghanistan has always been the focus of world opinion. When an event happens across the border region between the two countries it gets the attention of world community and

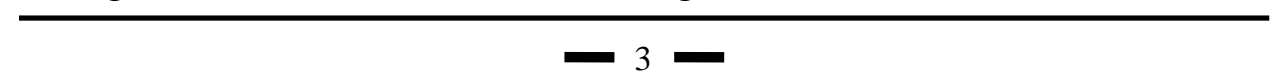




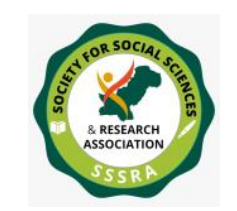

Pak. Journal of Int'L Affairs, Vol 4, Issue 2 (2021) The Influence of International Public Opinion ...

the world organizations and media take this to global level, thus impacting the regional affairs.

\section{Pak-Afghan Border Controversy: Focus Of International Public Opinion}

Pakistan and Afghanistan are two immediate neighbors and share about $2500 \mathrm{~km}$ common border known as Durand Line. Relationships between the two countries have been tense since the formation of Pakistan in 1947. When Pakistan was created, Afghanistan did not recognize Pakistan in United Nation, thus making the basis of dispute of international boundary between the two countries and even affecting their bilateral ties even today. The past five decades seen two great powers invasion of Afghanistan, deeply affecting its internal peace, stability and development. As Pakistan share the long porous border with Afghanistan, the internal security dynamics of Afghanistan have proven damaging for peace and stability in Pakistan. This border remained to be a source of contention between the two countries. Cross bounder terrorism, drug trafficking, illicit trade activities, and drug trafficking, smuggling, and free movements of terrorists across the border have deeply affected Pakistan. Pak-Afghan border management has remained to be a deep concern for the international community. International media, reports of global organizations and statements of world countries have always focused the management of Pak-Afghan border.

\section{Pakistan-Afghanistan Border Management Issues and Role Of International Public Opinion}

The unique geo-strategic location of Pakistan and Afghanistan make them significant countries in the world. For this reason, they have always been in the focus of world opinion. It remains the focus of research studies, international media, reports of international organizations etc. As border between the two countries remained porous until 2016 when Pakistan initiated the fencing work, it always led to cross border terrorism, illegal trade activities, drug trafficking, human trafficking etc. On Pakistani side, it includes areas in Khyber Pashtunkhuwa province and northern area in Balochistan province. (Wanxiang 2009)

The border dispute between Pakistan and Afghanistan remained resolved even after 70 years of Pakistan's inception. Through history of Pak-Afghan relations, there have been conflicts across border region, leading to killing and injuries of security personnel and civilians. The presence of extremist across border region and illicit commercial activities such as smuggling of weapons and drugs always posed threats to security of border area. 


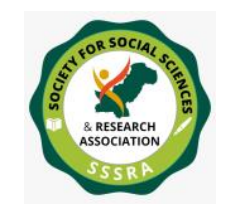

Pak. Journal of Int'L Affairs, Vol 4, Issue 2 (2021) The Influence of International Public Opinion ...

In long term goals, a nation can decide to change foreign policy and change friends or alliances, but it never compromise on its geographical location (Saikal, 2017, October 11). Pakistan-Afghanistan border region's controversies cannot eluded and highlighted negatively. It needs a peacemaking approach and needs support and proper guidance by world opinion.

Currently, in standpoint of world opinion, Pakistan-Afghanistan border region not merely trigger security threats but also leads to challenges of non-traditional security threats. For example, cross border terrorism and subversive activities of militant groups affect border management and peace in the region. Moreover, illicit trade and commercial activities across the border area deeply affect the formal trade between the two countries and trafficking of drug at Pak-Afghan border and subsequently it's spreading to different parts of the world got negative world opinion. Even though Pakistan and Afghanistan have signed several agreements in regards to this issues, but problems still remain unresolved in imports and exports. Additionally, the lack of adequate and proper banking services and lack of formal currency exchange service providers are other factors affecting Pakistan's formal trade volume with Afghanistan.

This border generates opportunities for informal trade between these two neighboring countries. The prevalence of illegal trade and smuggled goods not only damage bilateral trade but also affect the level of domestic producers. The illegal trade activities across Pak-Afghan border has deep and profound impacts on Pakistan's national economy, government, society and people. The loss to Pakistan's national economy through illicit trade activities is very high. It is one of the major factors in discouraging international investors. (United Nation Office on Drugs and Crime, 2011) These activities have badly discouraged foreign investment, thus creating negative international public opinions. These opinions have direct impact on Pak-Afghan border management. The international organization's reports and international public opinion have made Pakistan policy makers more sensitive on matter of border management. Pakistan and Afghanistan have agreed to establish joint trade markets along the border which is expected to promote legal trade activities between the people of the two countries.

The global organizations believe that illegal trade activities such as smuggling and drug trafficking affect Pak-Afghan border management. According to UNODC, "Pakistan is a transit, destination country for drugs and precursor chemicals. It is also a transit, source and destination country for trafficked persons and smuggling of migrants. This illicit traffic in narcotics and human beings poses significant challenges to border management, a critical issue for economic development and national security". The 


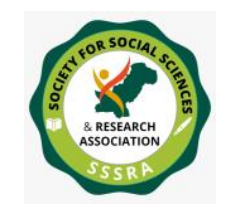

Pak. Journal of Int'L Affairs, Vol 4, Issue 2 (2021) The Influence of International Public Opinion ...

reports of global organizations directly influence border management between Pakistan and Afghanistan. These reports persistently highlight the need for border management and end to illicit trade activities across Pakistan-Afghanistan border areas (United Nation Office on Drugs and Crime, 2021). In a bid to ensure effective management of border and curb smuggling, Pakistan has decided to establish markets in its border areas with Afghanistan and Iran and formulate a comprehensive strategy in this regard. The markets would play crucial role for the prosperity of people living in border districts in Khyber Pashtunkhuwa and Balochistan. The establishment of such markets would bolster legal trade between the two countries and provide the residents of the areas employment and trade opportunities, thus a positive step to develop positive international public opinion (Dawn, 2021, January 19).

\section{Security Situation of Pak-Afghan Border: Role International Public Opinion}

Pakistan-Afghanistan border area has always been in the focus of international public opinion due to its uncertain security dynamics. In recent times, the influence of world opinion in regards to events which occurs at Pak-Afghan border region have enhanced due to increased role of media. International Public Opinion on Pak-Afghan border management is mixture of reports of international organizations reports, news of international media and role of social media. Whenever an incident took place in Afghanistan, it becomes the focus of global organizations, international media, social media, and foreign policy of world countries.

For instance, in March 2001, the Taliban regime in Afghanistan destroyed the centuries-old Buddhas of Bamiyan. This event became a burning issue of international media and the international community widely condemned and criticized it. The 'World Heritage Committee' had called for "the tragedy must not be allowed to repeat" the international community expressed their deep concerns over the event and the Taliban regime received negative world opinion. The international community emphasized the need for re-construction of the Buddhas. It is evident from the response of international community that international public opinion plays crucial role during emergency situations. It is evident form the reaction of world community that the world opinion always impact the situation in Afghanistan and bilateral issues between Pakistan and Afghanistan.

The massive drug trafficking and illicit trade activities across Pak-Afghan border have deep and profound impacts on Pakistan. Afghanistan has huge contribution in the production of opiates in the world comprising of opium, morphine, and heroin. It remained the most significant countries for analysis of drug trafficking. In 2009, 


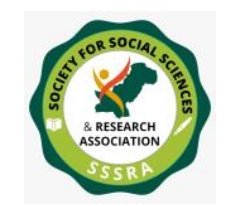

Pak. Journal of Int'L Affairs, Vol 4, Issue 2 (2021) The Influence of International Public Opinion ...

according to an estimation made by UNODC, $45 \%$ of illegal Afghan opiates are smuggled via Pakistan. Majority of this was transited to global market while the minority was used in Pakistan. In 2016, senior official of United Nation stated that Pakistan was the main country through which the Afghan narcotics are transported to the rest of the world. The UNODC also commend Pakistan's efforts managing border smuggling. Reports of global organizations always influence states' policies. The UN reports on narcotic trafficking also influenced Pakistani government policies to take steps to control drug smuggling at Pak-Afghan border (Mansoor, 2016, August 24).

When situation changes across Pak-Afghan border, the standpoint of the international community also changes, thus the international public opinion pursue this and express sum of views. For example, Afghanistan's national media in June 2019 reported that the United State-led coalition forces were carrying out search operations in mountainous region of eastern Afghanistan target the Taliban and al-Qaida. The Afghani media reported that Pakistan was deploying its troops across Pak-Afghan border area to contain the Taliban and militants of al-Qaeda group to enter into Pakistan's territory in time of the withdrawal of Pakistani troops.

Besides Pakistan, United States, China and Russia also seek end to cross-border attacks from the Afghan territory. These countries urge the government of Afghanistan and the Taliban to ensure that the Afghan territory is not used to threatened the security and stability of any other country. The four countries called as the Extended Troika on peaceful Settlement in Afghanistan also urged the Afghan government to engage openly with their Taliban counterparts. These countries also have a clear stance over the designations of Taliban individuals and entities and want the Un Security Council (UNSC) to review the designation of Taliban individuals and entities. "We call on all Afghans including the government of the Islamic Republic and the Taliban to ensure that terrorist groups and individuals do not use Afghan soil to threaten the security of any other country," they said in a joint statement issued in Washington. Pakistan has long been urging Afghanistan to end cross border attacks and make efforts to stop free movements of terrorist (Iqbal, 2021, May 1).

The United State Department urged neighboring countries of Afghanistan to support the Afghan peace process, saying that continued chaos and uncertainty in Afghanistan would be harmful for them. Pakistan has always supported peace process in Afghanistan and persistently saying that peace in Afghanistan is peace in Pakistan. The recent global media reports applaud that Pakistan has made serious measures to nudge the Taliban to the table of negotiations and convince them to commit to a ceasefire and continue their dialogue with the Afghan government (Iqbal, 2021, May 12). 


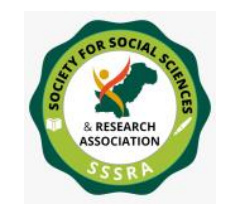

Pak. Journal of Int'L Affairs, Vol 4, Issue 2 (2021) The Influence of International Public Opinion ...

\section{Management of Pakistan's Border With Afghanistan}

Pakistan is bordered by Iran, Afghanistan, China and Indian. Pak-Afghan border management remains central to Pakistan's border management policies. For this, Pakistan has empowered Frontier Corps (FC) to shoulder responsibility to defend Pakistan's border areas.

The Article 3 paragraph 1 "THE FRONTIER CORPS ORDINANCE, 1959" rules: "Powers to maintain Frontier Corps. There shall continue to be maintained by the 2[Federal Government] the Frontier Corps forces or units as listed in the First Schedule, primarily for the better protection and administration of the external frontiers of Pakistan within the limits of or adjoining the 3[Tribal Areas] of 4[Pakistan]". And Article 7 (1) provides that: "Superintendence, command, control and administration of Frontier Corps. _(1) ("The Frontier Corps Ordinance, 1959" 2016). The superintendence of and command and control over the Frontier Corps shall vest in the 1[Federal Government], and the Frontier Corps shall be administered, commanded and controlled by the Inspector General and the Commandants in accordance with the provisions of this Ordinance and any rules made thereunder and such orders and instructions as may be made or issued by the 1 [Federal Government] from time to time."

Primary aim of border management is to ensure of national security and territorial integrity of Pakistan, to ensure peace and stability across border areas, to manage border affairs effectively, to promote economic development, and to establish good cordial relationships with neighboring countries.

The Afghan national media accused Pakistan of destroying the construction of dam. In year 2012, TIME reported the killing of Khan Wali, the supervisor of a dam in Afghanistan. After this, Afghan authorities accused Pakistan (Mashal, 2012, Decmber 3). Pakistan denies the Afghanistan baseless accusations.

\section{World Opinion Information and Pakistan-Afghanistan Border Management}

The world public opinion is based on published material which represents the opinions of international community through media and reports of global organizations. Management of Pakistan-Afghanistan has been taken to global level by media and role of international organizations. The world opinion plays crucial role and significantly impacts the border related issues between the two countries.

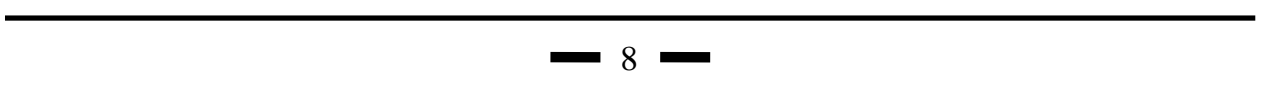




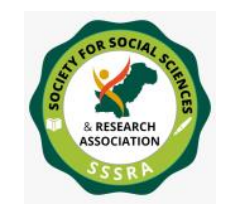

Pak. Journal of Int'L Affairs, Vol 4, Issue 2 (2021) The Influence of International Public Opinion ...

At global level, the viewpoint point of Pakistan's alleged support to terrorism has emerged from Afghanistan's accusations and became part of viewpoints of more and more countries. In South Asia, terrorism has been a serious issue, affecting Pakistan and Afghanistan. Afghanistan accuse Pakistan as the main supporter of terrorism in the region. The US and India also accuse Pakistan for supporting militancy. US president Donald Trump in 2018, took to twitter and labeled Pakistan as "safe haven" for terrorists claimed that United stated had given Pakistan more than $\$ 33$ billion but Pakistan did not played its due role. (Janjua, 2018, January 2). Responding to these accusations, Pakistan denied all US claims and presented its stance that it has suffered more losses than any other country during war on terror and deemed the US accusations the result of its defeat and frustration in Afghanistan. (Janjua, 2018, January 2).

Terrorist movements from Afghanistan side has a remained to be serious threat to peace in Pakistan. In first week of May, 2021, in two separate terrorist attacks in Pakistan's southwest and northwest resulted in killing of at least seven Army personnel and paramilitary troops and six other suffered to serious injuries. The terrorist attacked the paramilitary troops which were patrolling along the border fencing work with Afghanistan province of Kabul. According to Inter-Service Public Relations (ISPR) "Terrorists from across Afghanistan ambushed FC (Frontier Corps) troops moving for fencing. Four FC soldiers embraced shahadat (martyrdom), while six got injured" (Gul, 2015, July 5). Pakistan has been accusing the militant group Tehreek-e-Taliban Pakistan (TTP) for targeting security forces and civilians in Pakistan from "safe havens" across the border. China has a clear stance and urged the two countries to make measures to improve ties and make joint efforts to reconcile. China wants good cordial relationships between Pakistan and Afghanistan and has always expressed its willingness to play a constructive role in improving ties between the two immediate neighbors. (Reuters. 2021, May 5) At present, Pakistan is working on border fencing which is indeed a serious step to prevent cross border terrorism and peaceful environment across Pak-Afghan border. World opinion should support Pakistan's initiatives for border management and applaud its efforts. International public opinion can play crucial role in making Afghanistan inclined to take steps to border management and support Pakistan's efforts in this regard.

Media in Pakistan is based on multi-languages and an evident division is found between national language of Pakistan-Urdu and English news sources (Sarfaraz, 2019, September 9). In terms of print media, Urdu newspapers are read by people at larger level, especially people living in rural parts of the country have more attachment with it as compare to urban areas. On the other hand, the English media in the country is regarded comparatively liberal and professional. The audiences of English media 


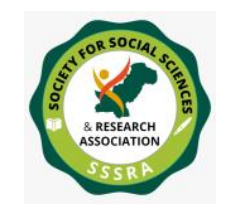

Pak. Journal of Int'L Affairs, Vol 4, Issue 2 (2021) The Influence of International Public Opinion ...

including television channels, print media and radio are smaller in number as compare to Urdu, but it has considerable influence among opinion makers, politicians, the business community and the upper strata of society. In addition to division between English and Urdu, the Pakistani media is also subjected to division on the basis of linguistic with a series of domestic language including Punjabi, Pashtu, Balochi, and Sindhi languages (Rehmat, 2019, July 21). Cross border terrorism and terrorist activities across the border area have made the border management ineffective, and has made it one of the important contents of world public opinion information. In this context, Pakistan's national media should play crucial role in counterterrorism measures.

\section{International Public Opinion Regulation and Its Influence On Pak-Afghan Border Management}

At present, Pakistan is fencing its border with Afghanistan as part of its border management system. Afghanistan vociferously opposed to fencing project initiated by Pakistan and have been persistently involved in attacks on Pakistan's paramilitary forces. The Afghan government's opposition to Pakistani efforts is appalling since the border management system is internationally considered extremely significant for ensuring security of borders. For instance, India has fenced its international border with Pakistan and also trying to illegally insert smart fences on the Line of Control with aim to cover many parts of the border with advanced surveillance system.

\section{Security of Pak-Afghan Border and the Need Of Positive World Opinion}

Several rounds of tri-nation dialogues have been held between Britain, Pakistan and Afghanistan with purpose to discuss border management system between Pakistan and Afghanistan but none has been productive. In year 2018, when Pak-Afghan border was closed, Britain convened the triangular conference in which Pakistan's National Security Advisor had participation. The main agenda discussed in the conference was related to closure of border. Indeed, Britain had convened the meeting in a bid to lessen tensions between Afghanistan and Pakistan, but the latter was not given any reassurances by the former. Pakistan had closed its border with Afghanistan After the latter was failed to cooperate management and end cross border terrorism (Yousafzai, 2018, November 14). Border management system is globally considered significant for security. Successful border control and effective management largely depend on joint surveillance systems, mutual agreements in regards to border closures. In case of Pak-Afghan border management, Pakistan typically take unilateral steps regarding border management due to lack of interest on the Afghan side. This un-equal regulation of porous border between Pakistan and Afghanistan need close coordination and cooperation. Cross border 


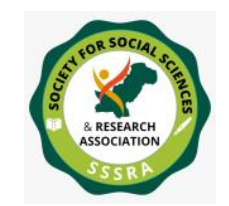

Pak. Journal of Int'L Affairs, Vol 4, Issue 2 (2021) The Influence of International Public Opinion ...

terrorism and free movements of terrorists have damaged Pakistan's global image. The inclusion of Pakistan on the Financial Action Task Force grey list is the reason that the global community has no faith in Pakistan's commitment to curb terrorism (Rasul, 2021, February 5). The international community should support Pakistan's counter-terrorism measures as well as make efforts to convince Afghanistan to support Pakistan's border management efforts. Positive world opinion on border management and appreciation of Pakistan's efforts would have positive and productive impacts on Pak-Afghan border management.

\section{Refugee problems and role of International Public Opinion}

Pakistan is home to large number of Afghan refugees. After formation of Pakistan in year 1947, the Durand line became international border between Pakistan and Afghanistan, dividing Pashtun community across border areas and making it citizens of both countries. Though the Pashtun community lives on both sides of the border, but their interconnections and cultural linkages remain close. After the Russian invasion in Afghanistan, huge number of Afghan people crossed border and took refuge in Pakistan. According to global media report, about $83 \%$ of those refugees were from Pashtun community. Pashtun is the main ethnic group in Khyber Pashtunkhuwa and a large number also occupy northern region of Balochistan province in Pakistan (Jing, 2013).

The global organization for Migration has given an extensive account of Afghan refugee. According to report, Pakistan and Iran are primary choice for the people of Afghanistan to migrate and take refuge. It further states that in year 2014 there were 1.6 million registered Afghan refugees in Pakistan, but the actual numbers are believed to be much higher (Bakrania, 2017). According to International Crisis Group majority of Afghan refugees in Pakistan belong to Pashtun ethnic community. (Bakrania, 2017) Large number of unregistered refugees are considered a threat to security of the local communities and they are accused for crime and militancy (Roehrs, 2015, March 9). Large number of unregistered Afghan refugees and their free movements across PakAfghan border is another factor related to border management issues. When security situation in Afghanistan becomes deteriorated, the Pashtun people in Afghanistan primarily take refuge in Pakistan, particularly in Khyber Pashtunkhuwa province (Border province with Afghanistan) and in northern parts of Balochistan (Pashtun dominated districts). Hence, border conflict is the main contradiction in Pak-Afghan bilateral relationships, and effective border management and cooperation is essential (Akhtar, 2009). In this context, the influence of world opinion information communication, enhance the use of global public opinion and its guidance towards the right path, reduce negative views, and effective management thus becomes essential. 


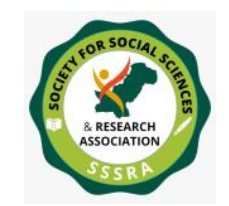

Pak. Journal of Int'L Affairs, Vol 4, Issue 2 (2021) The Influence of International Public Opinion ...

\section{Security of Pak-Afghan Border and the Need of World Opinion Involvement}

World opinion plays crucial role in international relations. It highlights a specific matter at global level influence it. When a serious issue emerges in a state or between the two states the people across the world through media, particularly through social starts sharing their views, thus influencing the specific matter. States and reports of global organizations directly influence a specific matter. The recent human rights violation by Israel became a burning issue of media, particularly people in Muslim world express their deep concerns over Israeli aggression. UN called for an immediate end to the violence (United Nation, 2021, May 16).. According to Pamuk, (2021, May 10), OIC condemned Israel for 'war crimes' and China called for UN Council Action to ensure immediate end to violence (The Associated Press, 2021, May 16). In addition, Pakistan and Turkey and other Muslim countries also condemned Israel's aggression and human rights violation and called for immediate end and permanent solution to the Palestine dispute. As a result of this, Israel and Hamas eventually agreed to cease-fire. World opinion played vital role in bringing an end to 11 days fighting which took lives of more the 250 people, most of the in Gaza (BBC News, 2021, May 21).

International public opinion plays crucial role in resolving disputes. Border management issues between Pakistan and Afghanistan is decades old. The two sides did not resolve the issues related to border management. World opinion on Pak-Afghan border management, particularly reports of global organizations on drug trafficking and smuggling give the border issue significance and persistently highlighted the need for an effective management of Pak-Afghan border. Involvement of world opinion and positive role of global organizations and international media will led to a permanent border related controversies and effective border management between Pakistan and Afghanistan.

\section{Role of Media}

Traditional media and its confluence with modern information technologies has increased the flow global news and ensured its availability to the general public faster than as it was in past. In ma modern era, the concept of world opinion is growing and it is gaining a much wider scope. Hence, it world opinion has become more influential than before. From the perspective of media convergence, the transmission of international public opinion is a result of the current information revolution. It is the product of the revolution in contemporary information. The content is the conveyance through the digital media of the power of worldwide public opinion and every natural or legal person 


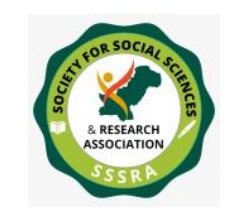

Pak. Journal of Int'L Affairs, Vol 4, Issue 2 (2021) The Influence of International Public Opinion ...

is the topic of communication and in a short space of time may generate the international area of public opinion.

The sources and users which develop world pinion in regards to PakistanAfghanistan relationships and their bilateral issues holds significance to security situation at Pak-Afghan border. In the age of media convergence and the emergence of extensive network of public opinion, mass information has become a reality. Because of the Internet's prominence, public opinion has become a gauge of societal emotion.

The national media of Pakistan, for example, have complete independence under media ethics and rules and regulation. Before the rise of private media networks and its extensive outlets in the country, print media played crucial role in providing information and shaping their views about domestic and global affairs. In modern times, with boom in television industry, role of media gets more significance in highlighting national and international affairs.

Besides television channels in Pakistan, a number of radio stations give free journalistic material (Rehmat, 2019, July 21). Therefore, the Pakistani media may make full use of the integrated media's role in guiding international public opinion in the direction of favorable reporting on the Pakistan-Afghanistan border. The relationship between world opinion and the general public will grow in the Media age, and they will occasionally engage with one other. The management of the Pakistan-Afghanistan border must take into account the engagement of the Media in order to attain the engagement of the whole population, as well as public opinion.

\section{China's Economic Initiatives and Implications for Pakistan-Afghanistan Relationships}

China has made unprecedented economic progress during the last few decades. It has become one of world's top economies. The economic initiatives of China such as "Belt and Road Initiative", "China-Pakistan Economic Corridor" and its trade linkages and economic cooperation Central Asia and other countries in Asia not merely have a great attraction but also realize economic complementarity and win-win situation. China's economic initiatives and its effective diplomatic role coupled with its all-weather relationships with Pakistan could play significant role in reducing trust gap between Pakistan and Afghanistan and cementing their bilateral relationships.

China economic initiatives such as its game changer projects-'Belt and Road Initiative' and China-Pakistan Economic Corridor (CPEC) could be effectively utilized to 


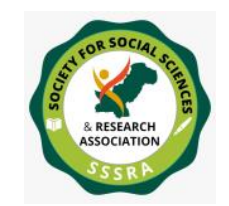

Pak. Journal of Int'L Affairs, Vol 4, Issue 2 (2021) The Influence of International Public Opinion ...

influence the world opinion and use it for Pakistan-Afghanistan border management and find more ways for economic development and stability of region. It could play role to ensure peaceful environment and Pakistan-Afghanistan border management. The engagement of Afghanistan in "Belt and Road Initiatives" will integrate it into regional cooperation and give it opportunities for economic development. China considers Afghanistan an important partner to help it in connecting to wider region through it BRI project (Safi, \& Alizada, 2018).

Pakistani policy makers also view CPEC a significant mega project for the country and support it. In Pakistan, few number of people from local parties and separatists are against the mega project and criticize it for not giving benefits to Pakistan (Deng, \& Li, 2017). In this context, Pakistan and China need to take effective measures such as countering false news and propaganda, deepening cooperation, and encouraging positive role of media of both the countries.

Peace, stability and prosperous environment across Pak-Afghan border have direct connection to the peace and stability of the whole world. The international public opinion plays crucial role determining success and failure of the border management. It is because when the international community approves the international public opinion becomes an effective tool of propaganda.

Just like the governance in a state, it must have the potential and strength to maintain productive governance, to be accepted globally and receive positive international public opinion. Hence, it is need of time to explore the actuality if theoretical breakthrough and development ahead in two areas-world opinion and Pakistan-Afghanistan border management.

\section{Conclusion}

The study examined Pakistan-Afghanistan border management and role of International Public Opinion. It is evident from the analyzed data that International Public opinion plays significant role in international politics. It influence the role of a state, foreign policy of a state and bilateral dispute between two countries. Traditional media tools and its confluence with modern technologies have led to increased flow of international mews available to the general public in more rapid pace and effectiveness as compare to traditional media. Hence, it's potential to shape the public opinions has enhanced, thus playing crucial role in developing public opinions and influencing an event.

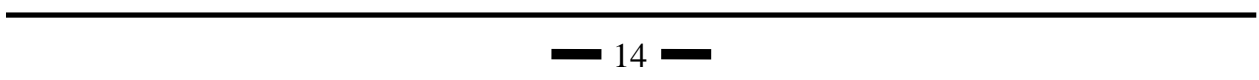




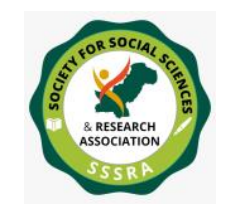

Pak. Journal of Int'L Affairs, Vol 4, Issue 2 (2021) The Influence of International Public Opinion ...

Management of Pak-Afghan border remains central to bilateral relationships between Pakistan and Afghanistan. International organizations and international media have always highlighted management border related issues between Pakistan and Afghanistan which include free movements of militants, drug trafficking, smuggling etc. The $2500 \mathrm{~km}$ long international border remained porous for almost 70 years. Pakistan remained sensitive regarding the management of its border with Afghanistan. Border security management is vital for stability of a country. A secure border is essential for security of a state. Hence, border management remains crucial part of Pakistan's security strategy. Globalization and changing dynamics of political culture have enhanced the importance of border areas. Pak-Afghan border has always been in eye of global community for number of reasons such as Conflict across border, border management issues, illegal commercial activities, drug trafficking, smuggling etc. The international public opinions about Pak-Afghan border management highlight the imperatives for effective border management policies. Pakistan has always perceived its porous border with Afghanistan a direct threat to its national security as well as damaging for its national economy. Fencing Pak-Afghan border is a milestone for Pakistan and a serious step towards border management.

Pakistan has started facing the border to ensure security and maintain peace across the international border. In addition to facing, Pakistan Army and paramilitary force are constructing new forts, border management to enhance surveillance. On the other hand, Afghanistan has never shown seriousness in regards to border management efforts made by Pakistan for permanent resolution of border management issues. The international public views also emphasize border management and improve surveillance across PakAfghan border. The world has realized that the porous border not only pose threat to world peace, but it also play major role in drug trafficking, human and goods, and smuggling along with other crimes. Fencing border will settle territorial controversy permanently and enhance legal trade activities between the two countries. Effective management of border would play crucial role in peace and stability of the region and would contribute in regional peace and economic development. 
The Influence of International Public Opinion ...

\section{References}

Akhtar, A. (2009). The New Great Game in Afghanistan and Pakistan. Economic and Political Weekly, 44(1), 36-40. Retrieved June 28, 2021, from http://www.jstor.org/stable/40278359

Bakrania, S. (2017). Cross border drivers of conflict: Pakistan-Afghanistan-Iran-Iraq. K4D Helpdesk Report. Brighton, UK: Institute of Development Studies.

BBC News. (2021, May 21). Israel-Gaza ceasefire holds despite Jerusalem clash. $B B C$ News https://www.bbc.com/news/world-middle-east-57195537

Calduch Cervera, R. (2017 May 17-19). The people as active participants in international life. In Beyond the Borders: People, spaces and Idea. [Paper Presented]. International Congress of Observer.

http://observare.ual.pt/conference/images/congresso_2017/Acta_IIICongresso_Rafael Calduch_EN.pdf

Dawn, (2021, January 19). PM orders early establishment of border markets. Dawn Newspaper. https://www.dawn.com/news/1602309.

Deng, A., \& Li, Y. (2017). Problems and countermeasures in the development of transport logistics in China-Pakistan economic corridor. World Journal of Research and Review, 5(6), 262716.

Gul, A. (2015, July 5). 7 Pakistani Troops Killed in Bomb Attack, Firefight. Voice of America. https://www.voanews.com/east-asia/7-pakistani-troops-killed-bomb-attackfirefight.

Iqbal, A (2021, May 12). Pakistan to continue supporting Afghan peace process: envoy. Dawn Newspaper. https://www.dawn.com/news/1623405.

Iqbal, A. (2021, May 1). Pakistan, US, China and Russia seek end to cross-border attacks from Afghanistan. Dawn Newspaper. https://www.dawn.com/news/1621413.

Janjua, H. (2018, January 2). Nothing but Lies and Deceit: Trump Launches Twitter Attack on Pakistan. The Guardian. https://www.theguardian.com/world/2018/jan/01/lies-anddeceit-trump-launches-attack-on-pakistan-tweet.

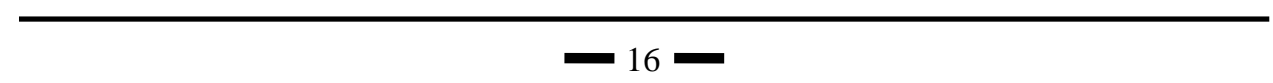




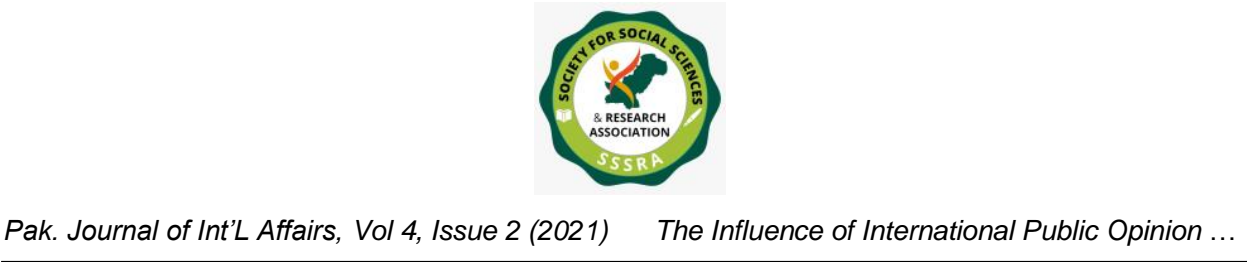

Jing, X. (2013). Refugee and border drug problems affect Pakistan's relations with Afghanistan, SHANGQING, No. (29).

Leiserowitz, A. (2007). International Public Opinion, Perception, and Understanding of global Climate Change. Human development report, 2008, 1-40

Mansoor, H (2016, August 24). Afghan drugs go to rest of world via Pakistan: UN report. Dawn Newspaper. https://www.dawn.com/news/1279631.

Mashal, M. (2012, Decmber 3). What Iran and Pakistan Want from the Afghan: Water. Time. Pulitzer Center. https://pulitzercenter.org/stories/what-iran-and-pakistan-wantafghans-water.

Omar, H. (2014, July 23-25). World Public Opinion and International Diplomacy. In Global and Regional Powers in a Changing World. [Paper Presentation]. FLACSOISA Joint Conference, Buenos Aires, Argentina.

Osée, U. B., Bijoux, B. T., Didier, S. B., \& François, E. O. (2019). Individuals and International Public Opinion as an Actor in International Relations. Open Journal of Social Sciences, 7(03), 478.

Pamuk, D. (2021, May 10). OIC's human rights body condemns Israel for 'war crimes.' https://www.aa.com.tr/en/middle-east/oic-s-human-rights-body-condemns-israel-forwar-crimes- $/ 2235038$

Rasul, X. (2021, February 5). Fencing the Afghanistan-Pakistan Border. South Asian Voices. https://southasianvoices.org/fencing-the-afghanistan-pakistan-border/

Rauf, S. \& Ahmad, S. (2019). Pak-Afghan Border Management: Developments and Controversies.https://www.researchgate.net/publication/343151848_PakAfghan_Border_Management_PAKMANAGEMENT_DEVELOPMENTS_AND_CONTROVERSIES

Rehmat, A. (2019, July 21). Why Pakistan Media is in Crisis. Dawn Newspaper. https://www.dawn.com/news/1495230.

Reuters. (2021, May 5). Pakistan says 4 soldiers killed in ambush by Afghan Militants along border. https://www.reuters.com/world/asia-pacific/pakistan-says-4-soldierskilled-ambush-by-afghan-militants-along-border-2021-05-05/

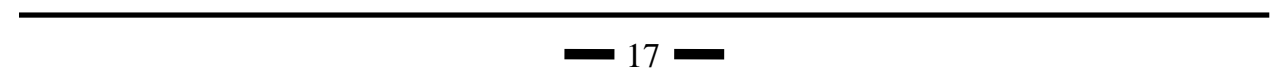




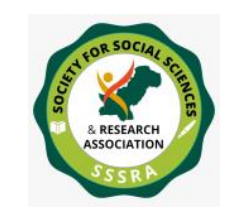

Pak. Journal of Int'L Affairs, Vol 4, Issue 2 (2021) The Influence of International Public Opinion ...

Roehrs, C. (2015, March 9). The Refugee Dilemma: Afghans in Pakistan between Expulsion and Failing Aid Schemes. Afghanistan Analysts Network. https://www.afghanistan-analysts.org/en/reports/migration/the-refugee-dilemmaafghans-in-pakistan-between-expulsion-and-failing-aid-schemes/

Safi, M., \& Alizada, B. (2018). Integrating Afghanistan into the Belt and Road Initiative. Review, Analysis and Prospects. Friedrich Ebert Stiftung. http://library.fes.de/pdffiles/bueros/kabul/15587.pdf

Saikal, A. (2017, October 11). Peace and Conflict between Afghanistan and Pakistan, Australian Outlook, Australian Institute of International Affairs. https://www.internationalaffairs.org.au/australianoutlook/peace-conflict-afghanistanpakistan/.

Sarfaraz, I. (2019, September 9). The others living among us. The News International. https://www.thenews.com.pk/magazine/you/523460-the-others-living-among-us.

Shahid, S. (2021, January 27). Land issues on Pak-Afghan border to be resolved: Langove. Dawn. https://www.dawn.com/news/1603825

The Associated Press. (2021, May 16). The Latest: China Calls for UN Council Action, Slams US. https://apnews.com/article/middle-easta240cfbb37bc3662a98d20e92bd38069

The Frontier Corps Ordinance, 1959, (2016). Ordinance No. XXVI OF 1959. http://nasirlawsite.com/laws/fc.htm

United Nation Office on Drugs and Crime. (2011, December 29). Examining the Dimensions, Scale and Dynamics of the illegal economy: A Case Study of Pakistan. Global Initiative: Against Transnational Organized Crime. https://globalinitiative.net/wp-content/uploads/2017/12/Examining-the-dimentionsscale-and-dynamics-of-illegal-economy.pdf.

United Nation Office on Drugs and Crime. (2021). Pakistan: Illicit Trafficking and Border Managment. https://www.unodc.org/pakistan/en/illicit-trafficking-and-bordermanagement.html.

United Nation. (2021, May 16). Security Council, UN chief calls for im mediate end to 'utterly appalling' Israel-Palestine violence. UN NEWS. https://news.un.org/en/story/2021/05/1092042. 
Wanxiang, Y. S. X. (2009). The Production and Trafficking of Drugs in PakistanAfghanistan Border Area [J]. South Asian Studies Quarterly, 1.

Yousafzai, Q. K. (2018, November 14). The Salience of Pak-Afghan Border Management. Pakistan Politico. https://pakistanpolitico.com/the-salience-of-pak-afghan-bordermanagement/. 